\title{
Gender, social cohesion and everyday struggles in South Africa
}

\author{
[R E F L E C T I O N S ]
}

\begin{abstract}
Since the advent of democracy in South Africa, far-reaching changes have taken place in many areas of society. While many positive changes have taken place in the new dispensation; however, the promise of democracy has not been fully met. The hope for collectivity and trust in the government system seems to be an ideal to which many are still striving. Using gender as a unit of analysis, this paper interrogates the complexities of democracy and the ideation of social cohesion in a country that contends with perpetual everyday struggles. I will also draw briefly from a research project that I conducted to highlight how women make meaning of their newly found 'freedom' and the ways in which they wrestle with perpetual challenges that so many of them continue to face.
\end{abstract}

\section{Introduction}

Numerous quantitative and qualitative investigations (McEwan, 2000; Mattes, 2002; Hassim, 2003; Makalela, 2004; Chipkin, 2007) have been conducted with the aim of examining, and seeking to understand, the changes that have taken place within South Africa since the advent of democracy. With democracy as the quintessence for many nations, one would imagine more tolerance and acceptance for diverse opinions and standpoints, however, in reality this is not yet the case. In a presentation he made at the $16^{\text {th }}$ annual Steve Biko Memorial Lecture held at the University of South Africa (12 November, 2015), Joaquim Chissano argued that one cannot begin to speak of a nation that resembles a "rainbow" when white skins continue to be absent whilst conversations addressing issues such as integration, cohesion, and togetherness are being
Puleng Segalo

Department of Psychology, University of South Africa, Pretoria segalpj@unisa.ac.za

\section{Keywords:}

cohesion, gender, citizenship, democracy, everyday struggles 
held. He argued that reconciliation cannot work if no concerted effort is made by everyone involved. In many ways he was echoing Biko (2004: 22) who proclaimed that: "Once the various groups within a given community have asserted themselves to the point that mutual respect has to be shown then you have the ingredients for a true and meaningful integration. At the heart of true integration is the provision for each man, each group to rise and attain the envisioned self. Each group must be able to attain its style of existence without encroaching on or being thwarted by another. Out of this mutual respect for each other and complete freedom of selfdetermination there will obviously arise a genuine fusion of the life-styles of the various groups. This is true integration" (emphases added).

Taking Biko's assertion into consideration, it can be argued that the premise of how changes started in 1994 (after the advent of democracy) is problematic and hence the current restlessness that is perceived. Emerging plutocratic tendencies pose a challenge as the gap between the rich and the poor continue to widen. It may be argued that these gaps and persistent inequalities are contributors to the instability that we see in the present day South Africa. There is, therefore, a need to change the mindset and illusion that we live in a free society when many continue to wear shackles of poverty, experience unemployment, gender discrimination and racism. In the quest for true independence and freedom there needs to be a shift from being mentally preoccupied with hopes and beliefs of what 'ought to be' to proactive engagement aimed at breaking the shackles. The notion of freedom continues to be complex - it remains a loud chorus that permeates through various corners of our society and makes hollow melodies of the imagined possibilities of what it should be. Freire (1997) warns that freedom is not easily attainable as it comes with responsibilities. He goes on to argue that there needs to be a readiness and willingness to get our hands dirty if we are to enjoy freedom. It therefore becomes critical to interrogate the challenges we face before thinking about possible solutions. To this end, epistemological frameworks and ideologies can guide us regarding the multiple complexities that should be taken into consideration when addressing issues of freedom and what it means.

It appears that there is a persistent distress that many South Africans continue to carry (Segalo: 2013; 2014) and it therefore becomes a challenge to imagine cohesiveness when people exist in a state of pain (either imagined or real). This paper aims at addressing the above issues with specific emphasis on gender related issues that continue to persist in a democratised South Africa. I will also draw briefly from a research project that I conducted to highlight how women make meaning of their newly found 'freedom' and the ways in which they wrestle with perpetual challenges that so many of them continue to face. 


\section{Equality and democracy: Women as "full" citizens}

After the advent of democracy, Black women were finally acknowledged as 'full citizens' of South Africa - however, inequality still looms as women's lived experiences continue to be minimally recognised. Citizenship is a contentious notion as its meaning is somewhat fluid and defined in a flexible manner depending on location, context, among other factors. Marshall (as cited in Yuval-Davis, 1991: 59) defines citizenship as "full membership in a community, which encompasses civil, political and social rights and responsibilities". Departing from this definition, Yuval-Davis (1991) problematises the notion of "community" as embedded in the definition and argues that it assumes a given collectivity that does not acknowledge continuing struggles and negotiations. She suggests that "collectivity should be constructed and not simply assumed" (ibid: 59). Yuval-Davis provides a useful critique that highlights the complex ways in which interaction among groups takes place. In pointing to the underlying discourses of what community means, she encourages us to critically engage with what it means to be a citizen. A democratised country where everyone is allowed to vote does not automatically mean cohesion and equal access to resources. Yuval-Davis (1991) calls for a theory of citizenship that acknowledges everyday struggles of race, class and gender. When we think of social cohesiveness we need to take into consideration the perpetual challenges, faced by many, that contribute towards struggles of attaining collectivity.

Forrest and Kearns (2001:2127) ask, "What does citizenship mean in a more multicultural and heterogeneous society, when the social contract between capital and labour has apparently broken down, when there is a growing gap between the politics of representation and the politics of intervention and where those inhabiting the same geographical territory may inhabit quite different social worlds"? This question is applicable to the present South African condition where the distribution of wealth continues to favour a few at the expense of the majority of citizens. Perceived as one of the most unequal countries in the world (Nattrass, \& Seekings, 2001; Ballard, Habib, Valodia, \& Zuern, 2005; Marais, 2011), it would come as no surprise that many people in South Africa who continue to suffer through persistent exploitation would take to the streets (for example, municipal workers, teachers, and mine workers) and demand better treatment and acknowledgement of their hard labour.

In her critical view of the concept of cohesion, Anzaldua (1999) suggested that in societies in which people co-exist, (different genders, races, classes, and so on) they become so entrenched in each other's lives that it becomes difficult to differentiate between insiders or outsiders. Raising the notion of intersectionality, Anzaldua asks us to seriously consider the interconnectedness of people's lived experiences. Intersectionality refers to the "overlapping" of social attributes such as gender, race, class, ability, religion, sexual orientation. This "structure" can be used to appreciate how systemic injustices 
and social inequalities occur on multifaceted levels. Intersectionality contends that the traditional notions of oppression such as racism, sexism and homophobia are not independent. Rather these interrelate and generate a system of oppression that resonates the "intersection" of multiple forms of discrimination. Kimberle Crenshaw (1989) proclaims that intersectionality denotes how black people (and more particularly black women) continue to exist at the crossroads of oppression. While women are now perceived as insiders (being allowed to attain education, enter the workplaces, etc.), their lived experiences render many of them as simultaneously insiders and outsiders as the spaces that many of them now occupy as "full citizens" continue to be unwelcoming and non-accommodating. Many women continue to carry the multiple burdens of having to take care of the household while working full time (Boonzaaier, 2005; Lambert \& Webster, 2010; Geldenhuys, 2011) thus making it difficult for them to fully integrate into the public sphere. These challenges of integration are in line with Biko's (2004) argument that true integration is not easily attained and that what is often talked about is artificial and therefore problematic. He goes further and asserts that: "... the people forming the integrated complex have been extracted from various segregated societies with their inbuilt complexes of inferiority and superiority and these continue to manifest themselves even in their 'nonracial' setup of the racial of the integrated complex. As a result the integration so achieved is a one-way course, with the whites doing all the talking and the blacks the listening. Let me hasten to say that I am not claiming that segregation is necessarily the natural order; however, given the facts of the situation where a group experiences privilege at the expense of others, then it becomes obvious that a hastily arranged integration cannot be the solution to the problem" (Biko 2004: 21-22).

While the artificial integration, to which Biko refers, was geared towards problems of race, I believe that these are also applicable in gender struggles. True democracy, or women emancipation, cannot be fully attained when women continue to exist in a "crooked room" where injustices such as gender inequality persist in crippling and rendering them invisible. The room remains "crooked" because most women occupy lower positions within workplaces while men mainly occupy senior and decision making positions (Barnette, 2004; James, Smith, Roodt, Primo, \& Evans, 2006; Catalyst, 2013). Can women and men truly function as equal citizens, and as effectively, when they do not occupy spaces equally and when there continues to be a lack of time for most women as they juggle between spaces? Harris-Perry (2011:38) makes an assertion that "inaccurate recognition is painful not only to the psyche but the political self, the citizen self". It is critical to note that human dignity is intricately linked to access to resources and security. Access to the workplace offers financial security, a luxury that most women were denied in the past and that many still struggle to attain. 
And yet, many women continue to experience what Michelle Fine (2002: 26) calls "the presence of an absence" where previously shut doors (e.g. workplaces and education attainment) are now open, and as mentioned earlier, many are now in the work force; however, for them this "presence" may remain somewhat of a facade as they continue to face challenges that are directly linked to the fact that they are women. Females are increasingly occupying the political sphere (in government/parliament), and their presence is undeniable, however the challenges pertaining to women's lived realities continue to confront them on a regular basis. This is consistent with Yuval-Davis' (1991: 66) assertion that "participation in the public domain does not equate to higher degree of empowerment". By seriously taking and paying attention to gender as a unit of analysis in theorising, a step closer to an understanding of the dynamics and complexities of gender politics in everyday life may be achieved. For example, the fact that South Africa continues to have one of the highest gender based violence rates in the world costing the country between R28.4 billion and R42.4 billion per year (KPMG Human and Social Sciences report, 2014) signifies that steps need to be taken to ameliorate the situation. Women (black women in particular) are often doubly discriminated (due to their gender and race) against and treated as second class citizens. One's citizenship determines access to resources and powers of a particular state. In many instances women and other ethnic minorities have limited access to such means. Indeed, this was the case for Black people and more specifically Black women during the apartheid era.

The attainment of social cohesion needs to be approached from the "intersection". That is, the intersection of gender inequality that continues to persist, the continuous struggles of accessing education, and silenced voices of many women who remain absent in the room when policies are made. There are a number of women's movements, one of them being the African National Congress Women's League (ANCWL) which aims at fighting for women's rights and standing up against gender based violence. The ANCWL has an unmistakable presence within the political sphere wherein they strive to directly engage with gender issues. While the league was formed on firm political grounds, their fight against gender injustice has been somewhat apolitical as they continue to be reluctant in challenging the persistent patriarchal status quo that renders numerous women as victims. Their voices continue to be inaudible and they are often the subject of critique as the contributions they make towards gender justice remain minimal due to their lack of critical engagement with socio-political issues that affect women and young people. For example, the ANCWL's absence could be felt in the recent South African student protests geared towards fighting academic exclusion based on class and race. Instead, the league organised a march in support of the current president whose actions has been perceived and critiqued by many as patriarchal. These glaring contradictions pose a challenge as they directly negate the principle of what the 
league stands for. The absence/shying away from confronting the gender injustices contribute towards the continuous quietening of women's voices.

While there has been an increase in the number of women (many of whom belonging to the women's league) occupying political spaces, silences around women struggles continue to persist; which begs the question: what decision making powers do they really have? This is an issue also highlighted by Yuval-Davis (2009: 9) in her argument that "women have paradoxical relationships to collectivities of belonging - ethnic, national, religious. On the one hand, women belong and are identified as members of the collectivity in the same way that men are. Nevertheless, there are always rules and regulations - not to mention perceptions and attitudes - specific to women". This may be perceived as "conditional belonging" where women are accepted as full citizens but with limited powers within the communities to which they belong. By being denied access to resources and freedom of movement (pre-1994), many women were morally excluded by the apartheid policies in South Africa. Although both black men and women suffered under apartheid, women suffered gendered oppression. For example, they were not allowed to buy property in their own names. Since the advent of democracy women can now own property and are allowed to vote thereby rendering them full citizens. However, this democratic freedom does not necessarily lend itself to automatic access to power and resources from which they were previously excluded. With this challenge in mind, I proffer an assertion that the past cannot be divorced from the present in that our history has direct implications for the current state of affairs. To suffer from convenient amnesia and selective attention instead of focusing on the need to reconcile without creating spaces for the confrontation of past injustices is problematic as it means that unhealed wounds will remain bleeding from within. To acknowledge the everyday struggles that people have to continuously contend with may offer some space to make sense of these intersecting issues and a possible understanding of how meaning is made.

\section{Some challenges and possibilities}

Current social and economic concerns can be attributed to historical systems of exclusion and discrimination. Many voices, which remain on the outskirts, struggle to find their way into the policy papers that determine and influence how decisions about people's lives are made. There is a need to create a scholarly stage where counter-stories and voices can be heard in a quest for democracy and cohesiveness. The dominant discourse that so often overshadows voices from down below may lead to what may be called 'enforced cohesiveness' where narratives of cohesion (rainbow nation) are circulated without acknowledging visible signs of non-cohesion (e.g. as can be seen in the constant media coverage of racism in schools, xenophobic attacks, and the so called 'hate-crimes'). I ask that a concerted effort to wrestle with these issues be made if we are to imagine a socially cohesiveness society in which people's every day experiences are acknowledged and not 
taken for granted. As Forest and Kearns (2011) argue, social cohesion is about "getting by" and "getting on with" the mundanities of everyday life. It is at these mundane levels that we need to zoom in and pay attention to the perpetual challenges with which many citizens continue to contend.

As I highlighted earlier, the complexities and challenges faced by the South African society cannot be divorced from gender politics. Issues that pertain to gender politics involve the interweaving of individual, family and societal understanding of how men and women construct their roles on a daily basis. One of the issues that beg attention is the persistent intimate partner violence that continues to be a predicament in many of our communities. It therefore becomes pertinent to also pay attention to how the formation of the South African family becomes disrupted as a result of various forms of gender violence (specifically intimate partner violence where victims are often women). The perpetual violence is linked to men's (particularly black men) positions within society. That is, violence is more likely to occur when a man is criminalised, and/or inhabits a space that does not acknowledge his masculinity, is unemployed and thus frustrated. The complexity of how gender based violence manifest itself needs to be troubled and understood in context if we are to get a deeper understanding of the socio-economic and historical underpinning that directly influence how men experience their lives daily. The apartheid regime contributed immensely in the emasculating of black men (for example, the persistent reference by whites to black adult men as "boys") and the remnants of these can still be felt in the present. These multiple and intersecting variables cannot be understood in isolation if we are to seriously engage with the notion of social cohesion in general and gender violence in particular. The importance of putting on the intersectionality lens is also highlighted by Van Niekerk, Tonsing, Seedat, Jacobs, Ratele \& McClure (2015: 1) who argue that "in South Africa, violence is marked by multiple social drivers, including widespread and racialized poverty, persistent unemployment, and extreme income inequality; patriarchal notions of masculinity that celebrate toughness and risk-taking; extensive exposure to abuse in childhood; access to firearms; excessive alcohol misuse; and weaknesses in law enforcement". These multiple social factors contribute towards the frustration and sense of helplessness and hopelessness that so many people experience as they navigate and attempt to make sense of their lives.

When people continue to exist in the zone of "non-being" (Fanon, 2008), it becomes difficult to imagine a cohesive space where everyone operates at the same level. Women are oppressed by gender lines, which are further aggravated by racial lines. For sustainable progress to take place, women's silenced knowings should be acknowledged and taken into consideration as failure to do so may hinder their innate potential. This warning is also stressed by Motsemme (2004: 4) in her involvement/research with women and the Truth and Reconciliation Commission where she asserted that "... the silences expressed

PINS [Psychology in Society] 49 • $2015 \mid 76$ 
by women telling their stories of loss and pain during the 1980s, were part of a deeply evocative language articulating women's embodied courage and consciousness of their precarious positions as mothers, wives, and sisters of often absent men". While the Truth and Reconciliation Commission offered a platform for women's lived experiences that had been silenced and ignored for a long time, more spaces need to be created to provide further opportunities for women to express their concerns. I would like to illustrate the importance of offering space to women's silenced knowings by briefly drawing from a research study I conducted.

To understand the experiences of Black women who grew up during apartheid South Africa, I conducted a study involving a group of women who are part of an embroidery project in Gauteng, South Africa (See Segalo 2011; 2013; 2014). South Africa has master narratives of reconciliation, gender equality and policies that ensure democracy in various facets of the society. The aim of my study was to offer the women an opportunity to carve visual narratives of their lives. The medium of telling stories through embroidery may conjure hidden feelings thus allowing thoughts to be visually expressed. In her article, The meanings of silence, Nthabiseng Motsemme (2004: 4) explains that "narrations of extreme human rights violations leave many with an inability to speak about their felt pain and loss. Language fails us, as it becomes inadequate to the task of conveying the experience of systematic degradations and humiliations". The making of embroideries afforded the women an alternative tool to deal with the inadequacy of spoken language by assisting them to visually reflect on their past and engage with their current experiences as full citizens with "equal rights" as men. When reflecting on being part of the research project, the women stressed the hard work and journey that still lies ahead before full cohesion can be attained. They pointed to how positive change is still yet to be felt as people are still poor with many being unable to afford basic human needs such as food. They zoomed in on the everyday challenges that they continue to face; for example, they expressed how food prices continuously increase while people's earnings do not. They further referred to the high unemployment rate, and how this affects young people who obtain educational qualifications but are unable to find employment. The women expressed anger as they had hoped for a better life from the new dispensation. While they acknowledged that oppression, due to the colour of their skin, has decreased, they argued that the remnants of apartheid could still be felt and seen. Racial imbalance is still rampant, and for the women in the project this meant: Where you come from determines what you get access to. They stressed that many people who fought in the struggle for freedom are not receiving the recognition they deserve, indeed most do not benefit for their efforts.

The women further revealed that while on the surface the schools were admitting everyone irrespective of race, in reality separation still existed within many schools. 
Moreover, while all are allowed to study wherever they want, many are restricted by financial constraints. For the women in the study, apartheid may be a thing of the past in terms of papers and policies, however; on the ground people are still struggling. They highlighted that education remained a critical catalyst to a better future; however, in many ways the attainment thereof still remains a privilege. Touching briefly on the status of education in township schools, the women expressed how children were sent to school only to find teachers who were not passionate about teaching.

Another crucial point raised by the women was the health issue. While they acknowledged that they had access to private hospitals; many did not go to them as they could not afford to pay for the treatment. Although there are public hospitals in many townships most lack resources needed to assist patients. The struggles the women suffered in their past were perceived to be directly linked to their current predicament. By highlighting their struggles, the women echoed the prophetic statement: "when we reject dominant western oppositional hierarchies of silence and speech, and instead adopt frameworks where words, silence, dreams, gestures, tears all exist interdependently and within the same interpretive field, we find that the mute always speak" (Motsemme, 2004: 910). It is during these moments of embracing intersectional existence of memories, experiences, and how lives are lived that we can move a step closer towards a possible social cohesion.

\section{Thinking out loud: A possible future}

If we continue to swim in the sea of unemployment, challenging heath care and schooling systems that are geared towards producing market ready individuals and not independent thinkers, then we will continue to produce individuals who perpetuate that which is already in place, and thus we cannot expect a transformed society. South Africa comes from a past of division, and the remnants of this can still be felt in the present. A unified approach is required to achieve a truly cohesive society. It is critical to acknowledge that various forms of inequalities continue to be felt and if a concerted effort to remove the veil of equality as painted on the canvasses called 'policies' is not made, we run the risk of having a society that continues to give birth to wounded generations. Social cohesion needs social, economic, and political reconstruction of the country. We ought to ask questions about who we are with multiple voices being given opportunities to respond. Motsemme (2004:5) asserts that "making efforts to link our stories to the everyday practices and fractured meanings of existence of individuals and communities is indeed a challenge, but also part of the unavoidable search of telling free and democratic stories". Therefore, if we are to imagine 'true cohesion', we need to create the spaces for multiple converging and diverging stories to be told. It is at these often uncomfortable intersections that true healing and reconciliation may be initiated. 
Social cohesion remains an epistemological dilemma that requires constant interrogation. When millions continue to live below the poverty line, how can cohesion be possible? When many stomachs continue to make a hollow sound, while others swim in abundance, we cannot begin to claim a socially cohesive society. Proclaimed as one of the most unequal societies in the world, South Africa continues to lag behind in the journey towards cohesion. Apartheid played a central role in ensuring inequality among members of the society, and over twenty years after the country's democracy cost accounting for the imbalances of the past remains in the imaginary realm as racism and gender inequality continue to loom. It is critical to acknowledge the interconnectedness of state functioning and its implications in the experiences of people's everyday lives (service delivery, wage disputes, health systems, education, etc). South Africa has a history of oppression, inequalities, and skewed privilege, and all these were normalised prior to 1994. For a long time these injustices made a "home" in the country.

Revisiting injustices of the past, many of which are still being maintained, is crucial. There needs to be a space for uncomfortable conversations if we are to imagine a free and truly democratic society. The persistent ghosts that lurk in the various dark corners of our existence need to be confronted and brought to light. We need to let the past guide us as to how we should deal with the present. Spaces for negotiation and confrontation of what 'being human' means need to take place as a starting point towards historical justice. We need to have conversations around "redress" as many people continue to live in poverty with minimal access to resources. These crucial aspects have to be met if we are to imagine a socially cohesive society.

\section{References}

Anzaldua, G (1999) Borderlands La Frontera: The New Mestiza.

San Francisco: Aunt Lute Books.

Ballard, R, Habib, A, Valodia, I \& Zuern, E (2005) Globalization, marginalization and contemporary social movements in South Africa. African Affairs, 104(417), 615-634.

Barnette, R C (2004) Women and work: Where are we, where did we come from, and where are we going? Journal of Social Issues, 60(4), 667-674.

Biko, S (2004) I write what I like. Johannesburg: Picador Africa (1978).

Boonzaier, F (2005) Women abuse in South Africa: A brief contextual analysis.

Feminism \& Psychology, 15(1), 99-103. doi:10.1177/0959353507088266 
Bouchaert, L (2011) Spirituality and economic democracy. Spirituality and Ethics in Management, 41-49.

Catalyst (2013) Women in male-dominated industries and occupations in US and Canada. Retrieved from http://www.catalyst.org/knowledge/women-maledominated-industries-and-occupations-us-and-canada

Chipkin, I (2007) Do South Africans exist?: Nationalism, democracy, and the identity of the people. Johannesburg: Wits University Press.

Crenshaw, C (1989) Demarginalizing the intersection of race and sex: A Black feminist critique of antidiscrimination doctrine, feminist theory and antiracist politics. University of Chicago Legal Forum, 138-167.

Fanon, F (2008) Black Skin White Masks. New York: Grove Press (1952-French).

Fine, M (2002) 2001 Carolyn Sherif Award Address: The presence of an absence. Psychology of Women Quarterly, 26, 25-35.

Friedkin, N (2004) Social cohesion. Annual Review of Sociology, 30, 409-425.

Freire, P (1997) Pedagogy of the oppressed. New York: The Continuum Publishing Company.

Forrest, R \& Kearns, (2001) A social cohesion, social capital and the neighbourhood. Urban Studies, 38(12), 2125-2143.

Geldenhuys, M (2011) Demographics of women in the workplace: A South African perspective, in Bosch, A (ed) South African Board for People Practices Women's Report 2011 (pp 12-23). Parktown: SABPP.

Harris-Perry, M V (2011) Sister citizen: Shame, stereotypes and Black women in America. New Haven: Yale University Press.

Hassim, S (2003) Representation, participation and democratic effectiveness; Feminist challenges to representative democracy in South Africa, in Goetz, A M \& Hassim, S (eds) (2003) No shortcuts to power: African women in politics and policy making. London: Zed Books (pp 81-109). 
James, T, Smith, R, Roodt, J, Primo, N \& Evans, N (2006) Women in the information and communication technology sector in South Africa.

Retrieved from: http://women-in-ict.meraka.csir.co.za

Jeannotte, S M (2010) Singing alone? The contribution of cultural capital to social cohesion and sustainable communities. International Journal of Cultural Policy, 9(1), 35-49.

KPMG Human and Social Services Report (2014) Too costly to ignore - the economic impact of gender-based violence in South Africa. Retrieved from: www.kpmg.co.za

Lambert, R \& Webster, E (2010) Searching for security: Case studies of the impact of work restructuring on households in South Korea, South Africa and Australia.

Journal of Industrial Relations, 52, 595-611. doi:10.1177/0022185610381672

Makalela, L (2004) Making sense of BSAE for linguistic democracy in South Africa.

World Englishes, 23(3), 355-366.

Marais, $H$ (2011) South Africa pushed to the limit: The political economy of change. Cape Town: UCT Press.

Mattes, R B (2002) South Africa: Democracy without the people? Journal of Democracy, 13(1), 22-36.

McEwan, C (2000) Engendering citizenship: Gendered spaces of democracy in South Africa. Political Geography, 19(5), 627-651.

Motsemme, N (2004) the meanings in silence. Rhodes Journalism Review, 24, 4-5.

Motsemme, N (2004) The mute always speak: On women's silences at the Truth and Reconciliation Commission. Current Sociology, 52, 909-932. doi:10.1177/0011392104045377

Nattrass, N \& Seekings, J (2001) Democracy and distribution in highly unequal economies: The case of South Africa. The journal of modern African studies, 39(03), 471-498.

Segalo, P (2011) Our lives through embroidery: Narrative accounts of the Women's Embroidery Project in post-apartheid South Africa. Journal of Psychology in Africa, 21(2), 229-238. 
Segalo, P (2013) Women, they too have their story: Re-imagining the female voice and body. Scriptura, 112, 1-10.

Segalo, P (2014) Embroidery as narrative: Black South African women's experiences of suffering and healing. Agenda, 28(1), 44-53.

Stanley, D (2003) What do we know about social cohesion: The research perspective of the Federal Government's Social Cohesion Research Network. The Canadian Journal of Sociology, 28(1), 5-17.

Van Niekerk, A, Tonsing, S, Seedat, M, Jacobs, R, Ratele, K \& McClure, R (2015) The invisibility of men in South African violence prevention policy: National prioritization, male vulnerability, and framing prevention. Global Health Action, 8. Retrieved from: http://www.ncbi.n/m.nih.gov/pmc/articles/PMC4520911/

Yuval-Davis, N (1991) The citizenship debate: Women, ethnic processes and the state. Feminist Review, 39, 58-68. 